\title{
Polyphenolic Characterisation of Vranac, Kratosija and Cabernet Sauvignon (Vitis vinifera L. cv.) Grapes and Wines from Different Vineyard Locations in Montenegro
}

\author{
R. Pajovic ${ }^{1}$, D. Raicevic ${ }^{1}$, T. Popovic ${ }^{1}$, P. Sivilotti ${ }^{2}$, K. Lisjak ${ }^{3}$, A. Vanzo ${ }^{3, *}$
}

(1) University of Montenegro, Biotechnical Faculty, Department for Viticulture and Oenology, Mihaila Lalica 1, 81000 Podgorica, Montenegro

(2) University of Nova Gorica, Wine Research Centre, Glavni trg 8, SI-5271 Vipava, Slovenia

(3) Agricultural Institute of Slovenia, Department of Fruit Growing, Viticulture and Oenology, Hacquetova 17, SI-1000 Ljubljana, Slovenia

Submitted for publication: October 2013

Accepted for publication: February 2014

Key words: Vranac, Kratosija, Cabernet Sauvignon, grape, polyphenols

\begin{abstract}
In Montenegro, red wines are produced predominantly, and Vranac accounts for nearly $80 \%$ of these wines, followed by Kratosija and Cabernet Sauvignon. In order to characterise polyphenols in red varieties, grapes were sampled from representative vineyards at harvest time during 2011 and 2012. The content and distribution of extractable anthocyanins, low-molecular mass proanthocyanidins (LMP) and highmolecular mass proanthocyanidins (HMP) in the seeds and skins of the grape berries were evaluated by applying a five-day extraction method using ethanol:water (12:88) as extraction solvent. On average, the highest content of LMP ( 2006 and $1690 \mathrm{mg} / \mathrm{kg}$ of grape fresh mass in years 2011 and 2012 respectively), HMP (2 705 and $2805 \mathrm{mg} / \mathrm{kg}$ in years 2011 and 2012 respectively) and anthocyanins (1 $035 \mathrm{mg} / \mathrm{kg}$ in the year 2011) was found in the Cabernet Sauvignon grapes. The highest content of anthocyanins $(1113 \mathrm{mg} / \mathrm{kg}$ in the year 2012) and the lowest content of LMP (1 103 and $846 \mathrm{mg} / \mathrm{kg}$ in years 2011 and 2012 respectively) was found in Vranac grapes. Kratosija grapes had the lowest anthocyanin content (456 and $517 \mathrm{mg} / \mathrm{kg}$ in years 2011 and 2012 respectively), and levels of LMP were similar to Vranac. The percentage distributions of LMP between skins and seeds were 34:66, 39:61 and 49:51, whereas the distributions of HMP between skins and seeds were 67:33, 62:38 and 64:36 for Vranac, Kratosija and Cabernet Sauvignon respectively. All varieties had more LMP in the seeds and more HMP in the skins of the grapes. The results obtained are important to better understand the polyphenolic potential of Montenegrin red grape varieties.
\end{abstract}

\section{INTRODUCTION}

Grape growing and winemaking in Montenegro started to develop in ancient times due to the geographical position and warm climate of the area. Winemaking is traditionally based on local varieties such as Vranac and Kratosija. Kratosija dominated until the outbreak of phylloxera, although Vranac became the preferred grape variety due to its lower heterogeneity and improved skin coloration (Ulicevic, 1966; Pejovic, 1988). Vranac and Kratosija are also cultivated in Macedonia, Bosnia and Herzegovina, Croatia and Serbia and are considered as indigenous varieties of the Western Balkan countries (Bozinovic, 2005). The winegrowing areas in Montenegro are increasing due to renewed investments in wine production, and are producing both local and international grape varieties. Vranac is the dominant grape among red grapes, whereas Kratosija is decreasing and Cabernet Sauvignon is increasing (Pajovic et al., 2011).
Vranac grapes are considered to have a strong polyphenol potential (Ivanova et al., 2011), as well as a high colour potential (Avramov, 1991). In contrast, Pajovic et al. (2009) reported about 300 to $400 \mathrm{mg} / \mathrm{L}$ of anthocyanins in young Vranac wines.

Flavonoids, i.e. anthocyanins and proanthocyanidins (also called grape condensed tannins), account for the major part of red wine polyphenols that have an impact on the sensorial quality of red wines; they are wine preservatives and the basis for ageing. Anthocyanins are responsible for the red colour (Ribéreau-Gayon, 1982) and proanthocyanidins for the colour stability (Somers, 1971), the taste of bitterness and the mouthfeel of astringency (Robichaud \& Noble, 1990). Generally, the astringency of proanthocyanidins increases with chain length and the bitterness decreases (Peleg et al., 1999; Chira et al., 2009). Other studies, however, report that differences in astringency are mainly due to the total

*Corresponding author: e-mail address: andreja.vanzo@kis.si

Aknowledgements: The authors would like to thank the Slovenian Research Agency for funding (BI-ME/012-13-017), the Ministry of Science of Montenegro, and Slovenia 's International Development Cooperation of the Ministry of Foreign Affairs (1811/2011-000070, 1811/2012-00053) and the Ministry of Economic Development and Technology (308/2013-864) 
content of proanthocyanidins in wines (Brossaud et al., 2001; Preys et al., 2006). Flavonoids, besides having technological importance, are also strong antioxidants that are important for human health (Rodrigo et al., 2011). The levels of anthocyanins and proanthocyanidins and the distribution of proanthocyanidins between the skin and seeds of grape berries are determined by grape variety, and by climatic and pedological conditions (Mattivi et al., 2002a, 2009). The grape variety also has an impact on the degree of proanthocyanidin polymerisation (Chira et al., 2009; Mattivi et al., 2009), which affects the extractability from skins and seeds during the winemaking process (Gambuti et al., 2009). Generally, skin proanthocyanidins are extracted earlier during the fermentation process and, as the maceration time increases, the extraction of seed proanthocyanidins increases (Peyrot des Gachons \& Kennedy, 2003).

The estimation of the polyphenolic potential allows the identification of differences in the polyphenol composition and provides factors with which to evaluate the oenological potential of the grape. Not many studies have been conducted on the polyphenol content of Vitis vinifera red grape varieties in the Western Balkan region, and the polyphenol content was obtained by the extraction of grape seeds and skin in organic solvents (Ivanova et al., 2010, 2011). The content and structure of the polyphenols extracted by the maceration process can differ from those extracted by means of strong organic solvents, since high-molecular mass proanthocyanidins are unlikely to be extracted to any great extent in a wine-like solution (Mattivi et al., 2009). The aim of this study therefore was to characterise Vranac, Kratosija and Cabernet Sauvignon grapes from representative Montenegrin vineyard locations according to the extractable polyphenol content and polyphenol distribution between the skin and the seeds of the grape berries. By using an extraction method that simulates the process of maceration (Mattivi et al., 2002b), the content of extractable total polyphenols, total anthocyanins, low-molecular mass proanthocyanidins (LMP) and high-molecular mass proanthocyanidins (HMP) have been determined separately in the skin and seeds of grape berries. The same polyphenol groups were evaluated in microvinified wines produced from the same grape.

\section{MATERIALS AND METHODS \\ Chemicals and reagents}

Methanol, ethanol, hydrochloric acid, sodium hydroxide, sodium bisulphite and $\mathrm{L}(+)$-tartaric acid were purchased from Sigma Aldrich (St. Louis, MO, USA) and Merck (Darmstadt, Germany). Ultra pure water was of Milli Q grade (Millipore Corporation, Billerica, MA, USA). The reagents Folin-Ciocalteu and vanillin were from Merck.

\section{Montenegrin wine region}

The Montenegrin wine region consists of two principal regions, one lying around the basin of Lake Skadar and the other along the coastal area on the Adriatic Sea. The majority of Montenegrin vineyards (almost 90\%) are located in the Podgorica district, in the basin of Lake Skadar (Fig. 1). The Podgorica district is characterised by a high Winkler index, making it favourable for growing red grape varieties, being $>2800$ and $>2300$ in 2011 and 2012 respectively. The Huglin index also proved to be high, at $>3700$ and $>3400$ in the same seasons. The average vegetation temperature was $23.1^{\circ} \mathrm{C}$ and $20.7^{\circ} \mathrm{C}$, whereas the precipitation in the same vegetation period was $311 \mathrm{~mm}$ and $902 \mathrm{~mm}$ in 2011 and 2012 respectively (MONSTAT, 2013).

\section{Grape sampling}

Grapes were sampled at the time of their technological maturity, between 3 and 25 September in 2011 and 2012. Grape samples of Vranac $(n=6)$, Kratosija $(n=5)$ and
A

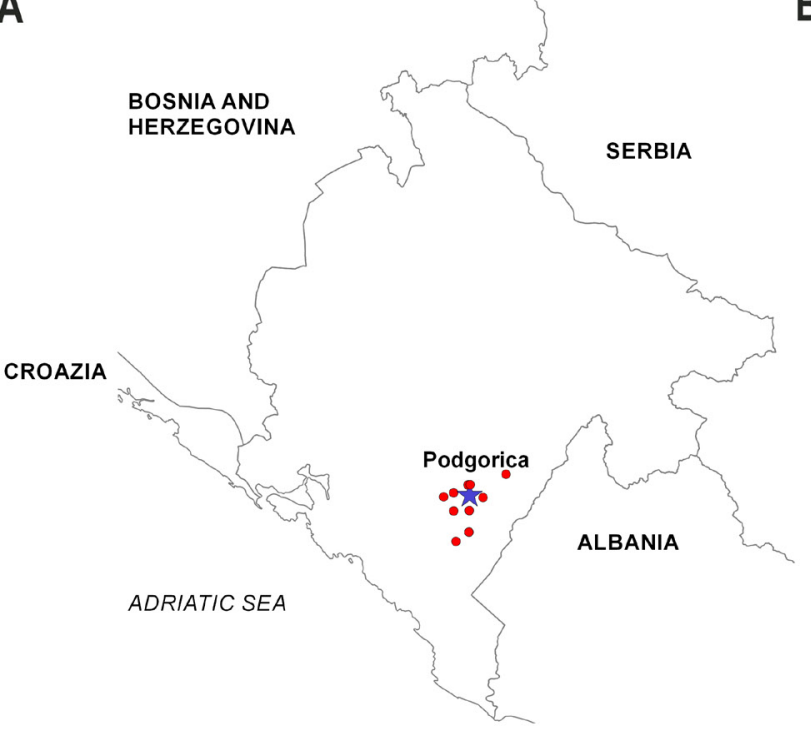

B

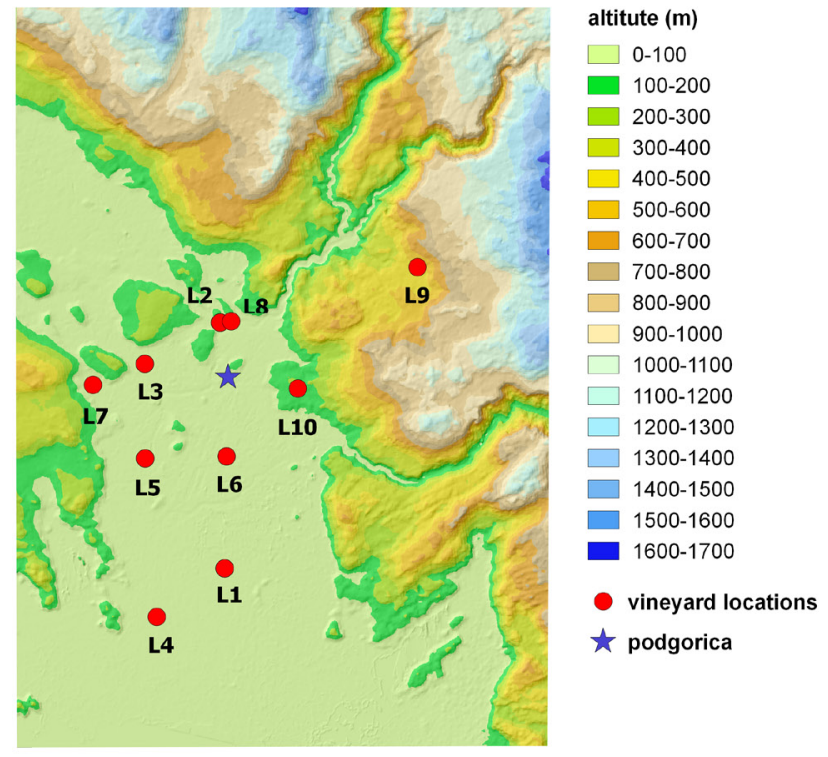

FIGURE 1

Geographical position of Montenegro and location of vineyards where grapes were sampled (A). Vineyard locations at different altitudes (B): 1 - Sipcanik, 2 - Rogami, 3 - Ljeskopolje, 4 - Zeta, 5 - Kokoti, 6 - Nikolj Crkva, 7 - Beri, 8 - Piperi, 9 - Kuci, 
TABLE 1

The characteristics of the vineyards from which grapes were sampled.

\begin{tabular}{llcccc}
\hline Locality & Rootstock & Planting year & Plant density & Training system & Row orientation \\
\hline L1 & Kober 5BB & 1978 & $4274(2.6 \times 0.9 \mathrm{~m})$ & Double Guyot & north - south \\
L2 & Teleki SO4 & 2006 & $6211(2.3 \times 0.7 \mathrm{~m})$ & Single Guyot & north - south \\
L3 & Kober 5BB & 2005 & $4000(2.5 \times 1.0 \mathrm{~m})$ & Double Guyot & north - south \\
L4 & Kober 5BB & 2008 & $4167(2.4 \times 1.0 \mathrm{~m})$ & Double Guyot & north - south \\
L5 & Kober 5BB & 2008 & $5714(2.5 \times 0.7 \mathrm{~m})$ & Single Guyot & north - south \\
L7 & Kober 5BB & 1989 & $6944(1.6 \times 0.9 \mathrm{~m})$ & Double Guyot & north - south \\
& & & KRATOSIJA & north - south \\
L1 & 1103 Paulsen & 2006 & $5495(2.6 \times 0.7 \mathrm{~m})$ & Single Guyot & north - south \\
L2 & Teleki SO4 & 2006 & $6211(2.3 \times 0.7 \mathrm{~m})$ & Single Guyot & north - south \\
L3 & Kober 5BB & 2005 & $4000(2.5 \times 1.0 \mathrm{~m})$ & Double Guyot & north - south \\
L6 & Kober 5BB & 1996 & $4808(2.6 \times 0.8 \mathrm{~m})$ & Double Guyot & north - south \\
L9 & Kober 5BB & 1983 & $2500(2.0 \times 2.0 \mathrm{~m})$ & Pergola & north - south \\
& & CABERNET SAUVIGNON & & north - south \\
L1 & 1103 Paulsen & 2006 & $5495(2.6 \times 0.7 \mathrm{~m})$ & Single Guyot & north - south \\
L2 & Teleki SO4 & 2006 & $6211(2.3 \times 0.7 \mathrm{~m})$ & Single Guyot & Single Guyot \\
L5 & Kober 5BB & 2008 & $5714(2.5 \times 0.7 \mathrm{~m})$ & north - south & north - south \\
L10 & Kober 5BB & 1996 & $4808(2.6 \times 0.8 \mathrm{~m})$ & Single Guyot & east - west \\
\hline
\end{tabular}

Cabernet Sauvignon $(\mathrm{n}=6)$ were collected from vineyards located in the Podgorica wine-growing district (Fig. 1A). Vineyard characteristics are presented in Table 1. The yield of the vineyards was not reduced and water was applied by drip irrigation, thus water status in the field was not checked. Approximately $20 \mathrm{~kg}$ of grapes from each vineyard were representatively sampled. The vineyard locations were as follows: Sipcanik (1), Rogami (2), Ljeskopolje (3), Zeta (4), Kokoti (5), Nikolj Crkva (6), Beri (7), Piperi (8), Kuci (9) and Kakaricka Gora (10). Location 9 and location 10 lie at 250 and $400 \mathrm{~m}$ above sea level, while the others lie between 25 and $50 \mathrm{~m}$ above sea level (Fig. 1B).

\section{Determination of grape physicochemical characteristics} Grape samples of 100 berries each were representatively collected from the $20 \mathrm{~kg}$ sample and weighed. Total soluble solids (TSS), titratable acidity and the $\mathrm{pH}$ of the berry juice were determined following International Organisation of Vine and Wine procedures (OIV, 2011).

\section{Polyphenol extraction from grapes}

A selective extraction of polyphenols from the skins and seeds of grape berries that simulates the maceration process of red wines was used (Mattivi et al., 2002b; Vacca et al., 2009). Skins and seeds of $200 \mathrm{~g}$ of randomly sampled grape berries were manually separated and separately extracted for five days at $30^{\circ} \mathrm{C}$ in a $200 \mathrm{~mL}$ solution consisting of ethanol:water $(12: 88 \mathrm{v} / \mathrm{v}), 100 \mathrm{mg} / \mathrm{L}$ of $\mathrm{SO}_{2}, 5 \mathrm{~g} / \mathrm{L}$ tartaric acid and a $\mathrm{pH}$ value adjusted to 3.2 (with $\mathrm{NaOH}$ ). The extracts were shaken by hand once a day. Skins and seeds were removed from the hydro-alcoholic solution after five days and the skin extract was centrifuged for $10 \mathrm{~min}$ at $3500 \times \mathrm{g}$. Extracts were poured into dark glass bottles, flushed with nitrogen and stored at $4^{\circ} \mathrm{C}$ until required for spectrophotometric analyses. Analyses were conducted four months later.

\section{Vinification}

The harvested grapes $(20 \mathrm{~kg})$, which originated from different localities, were microvinified at the winery of the Biotechnical Faculty in Podgorica during the 2011 and 2012 seasons. The grapes were destemmed and crushed and sodium metabisulphite was added (5 $\mathrm{g}$ of $\mathrm{SO}_{2}$ to 100 $\mathrm{kg}$ of grapes). Vinification was conducted by spontaneous fermentation without repetitions due to the limited grapes available for vinification. Maceration lasted for seven days at a temperature between 25 and $28^{\circ} \mathrm{C}$. The cap was punched down twice a day throughout the skin-contact period. Wines were decanted (sugar level $<2 \mathrm{~g} / \mathrm{L}$ ) without pressing at the end of alcoholic fermentation. Free-run wines were stored at room temperature. After the spontaneous malolactic fermentation, the wines were decanted again and $\mathrm{SO}_{2}$ was added. Polyphenols in the wines were analysed four months after the fermentation.

\section{Spectrophotometric analyses}

Analyses were performed using a Varian Cary 100 spectrophotometer (Bio Tech, Maryland, USA), as described by Di Stefano and Guidoni (1989) and Di Stefano et al. (1989), under optimising conditions for red wine analysis (Rigo et al., 2000). Polar compounds such as sugars, organic acids, amino acids and free $\mathrm{SO}_{2}$, which could interfere with the assays, were removed by clean-up of grape extracts and wine using Sep-Pak classic (0.35 g) C-18 columns supplied by Waters (Milford, MA, USA). 


\section{Total polyphenols}

Total polyphenols (TP) were assessed by the reduction of Folin-Ciocalteu reagent to blue pigments caused by polyphenols in alkaline solution. A realistic estimation of total polyphenols can be obtained only after preliminary cleaning of samples from other compounds (free $\mathrm{SO}_{2}$, sugars, etc.) that interfere with the assay (Di Stefano \& Guidoni, 1989). When the absorbance was between 0.3 and $0.6 \mathrm{AU}$ (the linear response range), the results were expressed against the corresponding blank as $(+)$-catechin $=186.5 \times$ $\mathrm{A} \times \mathrm{d}$ in $\mathrm{mg} / \mathrm{kg}$ grape fresh mass $(\mathrm{FM})$ or in $\mathrm{mg} / \mathrm{L}$ of wine; $\mathrm{A}$ $=$ absorbance and $\mathrm{d}=$ sample dilution.

\section{High-molecular mass proanthocyanidins}

HMP were evaluated by transformation into cyanidin (Di Stefano et al., 1989). When the absorbance was between 0.3 and $0.6 \mathrm{AU}$ the results were expressed against the corresponding blank as cyanidin chloride $=1162.5 \times \Delta \mathrm{A}$ $\times \mathrm{d}$ in $\mathrm{mg} / \mathrm{kg}$ grape $\mathrm{FM}$ or in $\mathrm{mg} / \mathrm{L}$ of wine; $\Delta \mathrm{A}=$ difference in absorbance between sample and blank, and $\mathrm{d}=$ sample dilution. The method provides a good estimation for the evaluation of HMP (Vrhovsek et al., 2001).

\section{Low-molecular mass proanthocyanidins - index of vanillin}

The catechins and proanthocyanidins reactive to vanillin were analysed according to the optimised and controlled vanillin$\mathrm{HCl}$ method of Broadhurst and Jones (1978), following the conditions described by Di Stefano et al. (1989). The method provides an estimation of the free carbon 6 and carbon 8 of the A-ring of both catechins and proanthocyanidins. This index decreases with the increase in polymerisation, because mainly carbon 6 and carbon 8 are involved in polymerisation bonds. The method provides a good estimation of free flavanols and a low degree of polymerised flavanols. When the absorbance was between 0.2 and $0.4 \mathrm{AU}$, the LMP were evaluated as $(+)$-catechin $=290.8 \times \Delta \mathrm{A} \times \mathrm{d}$ in $\mathrm{mg} / \mathrm{kg}$ grape $\mathrm{FM}$ or in $\mathrm{mg} / \mathrm{L}$ of wine; $\Delta \mathrm{A}=$ difference in absorbance between sample and blank and $\mathrm{d}=$ sample dilutions.

\section{Total anthocyanins}

Total anthocyanins (TA) were determined on the basis of maximal absorbance in the visible range (536 to $542 \mathrm{~nm}$ ). When the absorbance was between 0.3 and $0.6 \mathrm{AU}$, the results were expressed against the corresponding blank as $\mathrm{TA}=\mathrm{A} \times 26.6 \times 4 \times \mathrm{d}$ in $\mathrm{mg} / \mathrm{kg}$ grape $\mathrm{FM}$ or in $\mathrm{mg} / \mathrm{L}$ of wine ( $\mathrm{d}=$ sample dilution) by assuming an average absorbance of the mixture of anthocyanins extracted from Cabernet Sauvignon grapes (average MW $=500 \mathrm{Da}, \varepsilon=18800 \mathrm{M}^{-1}$ $\mathrm{cm}^{-1}$ in 70:30:1 ethanol:water:HCl solution) (Di Stefano et al., 1989).

\section{Statistical analysis}

Data was processed by ANOVA ( $p$ indicated) and, when significant, the means were separated using Tukey's honest significant difference (HSD) test $(p<0.05)$. Statistical analysis was performed using the Statgraphics Centurion XVI program (Manugistics Inc., Rockville, MD, USA).

\section{RESULTS AND DISCUSSION}

Physicochemical characteristics of Vranac, Kratosija and Cabernet Sauvignon grapes at the time of harvest The physicochemical characteristics of Vranac, Kratosija and Cabernet Sauvignon grapes at the time of harvest from different vineyard locations in the Podgorica district in 2011 and 2012 are listed in Table 2. The average mass of 100 berries did not differ significantly between the Vranac and Kratosija varieties in 2011 (240 g and $242 \mathrm{~g}$, respectively) and 2012 (217 and 222 g, respectively) (Table 2). The average berry mass of Cabernet Sauvignon was significantly lower (113 g in 2011 and 2012) than that of the Vranac and Kratosija varieties in both years. Grape berries of Vranac and Kratosija are almost twice as heavy as those of Cabernet Sauvignon and have a significantly lower percentage of skins by berry weight compared to Cabernet Sauvignon grapes. Average TSS content (Table 2) at the time of sampling was the highest in the grape juice of Kratosija $\left(23.8^{\circ}\right.$ Brix in 2011 and 2012), followed by Cabernet Sauvignon (23.7 and $22.5^{\circ}$ Brix). Vranac grape juice reported the lowest TSS values (21.7 and $20.7^{\circ}$ Brix).

The acidity of the grape juice was low, as is typical for warm climates such as the Montenegro region. Significant lower titratable acidity (TA) was assessed in the Vranac grapes $(5.4 \mathrm{~g} / \mathrm{L}$ and $4.9 \mathrm{~g} / \mathrm{L}$ for 2011 and 2012, respectively) compared to the Kratosija grapes $(6.4 \mathrm{~g} / \mathrm{L}$ and $6.5 \mathrm{~g} / \mathrm{L})$, even if not significantly different from Cabernet Sauvignon $(5.8 \mathrm{~g} / \mathrm{L}$ and $6.0 \mathrm{~g} / \mathrm{L})$. At the time of harvest, Vranac grapes proved to be higher in $\mathrm{pH}$ value compared to Kratosija and Cabernet Sauvignon in both years, although differences among the varieties were not statistically significant.

Contents of extractable total polyphenols, low- and high-molecular mass proanthocyanidins and total anthocyanins in grapes of Vranac, Kratosija and Cabernet Sauvignon

The content of extractable polyphenols (in $\mathrm{mg} / \mathrm{kg}$ grape FM) in Vranac, Kratosija and Cabernet Sauvignon at the time of harvest from different vineyard locations in Podgorica district in 2011 and 2012 is shown in Table 3. The concentration levels represent the sum of extractable polyphenols in the skin and in the seeds of grape berries evaluated as the content in $\mathrm{mg} / \mathrm{kg}$ of grape FM.

The mean content of total extractable polyphenols in the skin and seeds of grape berries was the highest in Cabernet Sauvignon in both years $(2705 \mathrm{mg} / \mathrm{kg}$ and $2017 \mathrm{mg} / \mathrm{kg}$ in 2011 and 2012, respectively) and was significantly higher compared to Kratosija grapes (1 $699 \mathrm{mg} / \mathrm{kg}$ and $1097 \mathrm{mg} / \mathrm{kg}$ ). The content of extractable polyphenols in Vranac grapes was intermediate $(1908 \mathrm{mg} / \mathrm{kg}$ and $1598 \mathrm{mg} / \mathrm{kg}$ in 2011 and 2012, respectively), but not significantly different compared to Kratosija and Cabernet Sauvignon. The results presented here are in compliance with the extractable total polyphenol content in red Vitis vinifera grape varieties grown in Slovenia. Vrhovsek et al. (2002) showed that the average extractable total polyphenol content in grapes of red Vitis vinifera varieties in a two-year study was between 1100 and $2100 \mathrm{mg} / \mathrm{kg}$ grape FM, and the highest content was reported in Cabernet Sauvignon grapes (2 000 to 
TABLE 2

Physicochemical characteristics (MB - Mass of 100 berries, TSS - Total soluble solids, TA - Titratable acidity, SKIN/BERRY percent of skin by berry weight) of Vranac, Kratosija and Cabernet Sauvignon grapes at the time of harvest.

\begin{tabular}{|c|c|c|c|c|c|c|c|c|c|c|}
\hline \multicolumn{6}{|c|}{2011} & \multicolumn{5}{|c|}{2012} \\
\hline Locality & $\begin{array}{c}\mathrm{MB} \\
(\mathrm{g})\end{array}$ & $\begin{array}{c}\text { TSS } \\
\left({ }^{\circ} \text { Brix }\right)\end{array}$ & $\begin{array}{c}\mathrm{TA}(\mathrm{g} / \mathrm{L} \\
\text { tartaric acid })\end{array}$ & $\overline{\mathrm{pH}}$ & $\begin{array}{c}\text { SKIN/ } \\
\text { BERRY }(\%)\end{array}$ & $\begin{array}{l}\mathrm{MB} \\
(\mathrm{g})\end{array}$ & $\begin{array}{c}\text { TSS } \\
\left({ }^{\circ} \text { Brix }\right)\end{array}$ & $\begin{array}{c}\mathrm{TA}(\mathrm{g} / \mathrm{L} \\
\text { tartaric acid })\end{array}$ & $\mathrm{pH}$ & $\begin{array}{c}\text { SKIN/ } \\
\text { BERRY }(\%)\end{array}$ \\
\hline \multicolumn{11}{|c|}{ VRANAC } \\
\hline L1 & 257 & 22.9 & 5.0 & 3.53 & 8.8 & 250 & 19.2 & 4.7 & 3.56 & 9.8 \\
\hline L2 & 219 & 22.7 & 5.5 & 3.48 & 9.8 & 207 & 21.6 & 5.1 & 3.45 & 10.4 \\
\hline L3 & 210 & 22.3 & 5.3 & 3.46 & 10.2 & 200 & 23.5 & 5.3 & 3.45 & 10.6 \\
\hline L4 & 258 & 19.6 & 5.6 & 3.50 & 9.3 & 214 & 17.6 & 5.6 & 3.40 & 10.9 \\
\hline L5 & 224 & 23.1 & 5.1 & 3.60 & 9.9 & 212 & 23.0 & 4.0 & 3.59 & 10.2 \\
\hline L7 & 271 & 19.6 & 5.6 & 3.69 & 9.1 & 217 & 19.5 & 4.6 & 3.58 & 10.7 \\
\hline Mean & $240 a$ & 21.7 & $5.4 \mathrm{~b}$ & 3.54 & $9.5 \mathrm{~b}$ & $217 a$ & $20.7 \mathrm{~b}$ & $4.9 \mathrm{~b}$ & 3.51 & $10.4 \mathrm{~b}$ \\
\hline \multicolumn{11}{|c|}{ KRATOSIJA } \\
\hline L1 & 238 & 22.0 & 6.3 & 3.57 & 10.6 & 225 & 22.5 & 9.0 & 3.36 & 11.2 \\
\hline L2 & 242 & 24.4 & 6.2 & 3.47 & 10.4 & 224 & 24.5 & 5.9 & 3.30 & 10.9 \\
\hline L3 & 233 & 28.0 & 6.7 & 3.53 & 10.1 & 211 & 25.4 & 6.6 & 3.58 & 11.4 \\
\hline L6 & 244 & 22.6 & 6.1 & 3.49 & 10.7 & 195 & 24.6 & 4.9 & 3.36 & 11.9 \\
\hline L9 & 255 & 22.2 & 6.6 & 3.48 & 9.7 & 253 & 21.8 & 6.0 & 3.46 & 9.8 \\
\hline Mean & 242 a & 23.8 & $6.4 \mathrm{a}$ & 3.51 & $10.3 \mathrm{~b}$ & 222 a & $23.8 \mathrm{a}$ & $6.5 \mathrm{a}$ & 3.41 & $11.0 \mathrm{~b}$ \\
\hline \multicolumn{11}{|c|}{ CABERNET SAUVIGNON } \\
\hline L1 & 131 & 22.3 & 5.9 & 3.41 & 12.5 & 95 & 22.9 & 7.1 & 3.20 & 16.2 \\
\hline L2 & 128 & 22.9 & 5.9 & 3.48 & 13.1 & 112 & 22.9 & 5.6 & 3.44 & 14.4 \\
\hline L5 & 83 & 23.1 & 6.5 & 3.64 & 15.8 & 133 & 22.1 & 5.8 & 3.40 & 12.6 \\
\hline L6 & 117 & 24.1 & 5.9 & 3.41 & 13.6 & 110 & 22.5 & 5.8 & 3.40 & 15.4 \\
\hline L8 & 107 & 25.7 & 5.6 & 3.45 & 15.9 & 111 & 21.2 & 5.6 & 3.35 & 15.1 \\
\hline L110 & 110 & 24.0 & 5.1 & 3.58 & 15.4 & 118 & 23.2 & 6.0 & 3.68 & 13.9 \\
\hline Mean & $113 \mathrm{~b}$ & 23.7 & $5.8 \mathrm{~b}$ & 3.50 & $14.4 \mathrm{a}$ & $113 \mathrm{~b}$ & $22.5 \mathrm{ab}$ & $6.0 \mathrm{ab}$ & 3.41 & $14.6 \mathrm{a}$ \\
\hline sign. $F$ & $* * *$ & n.s. & $* * *$ & n.s. & $* * *$ & $* * *$ & $*$ & $*$ & n.s. & $* * *$ \\
\hline
\end{tabular}

ANOVA was used to compare data (n.s. not significant, $* p \leq 0.05, * * p \leq 0.01$, $* * * p \leq 0.001$ ). Different lower-case letters indicate significant differences of means between varieties using Tukey's HSD test $(p \leq 0.05)$.

$2100 \mathrm{mg} / \mathrm{kg}$ ). The extractable anthocyanin content of the grapes did not differ significantly between Vranac and Cabernet Sauvignon in 2011 (1 $035 \mathrm{mg} / \mathrm{kg}$ and $960 \mathrm{mg} / \mathrm{kg}$, respectively), whereas the extractable anthocyanin content of grapes harvested during 2012 was significantly higher in Vranac grapes compared to Cabernet Sauvignon grapes (1 $113 \mathrm{mg} / \mathrm{kg}$ and $861 \mathrm{mg} / \mathrm{kg}$ respectively). Kratosija grapes proved to have a significantly lower content of extractable anthocyanins (Table 3) compared to Vranac and Cabernet Sauvignon in both years $(456 \mathrm{mg} / \mathrm{kg}$ and $517 \mathrm{mg} / \mathrm{kg}$ in 2011 and 2012, respectively). The extractable anthocyanin content (determined by the same method) in Slovenian red grapes was 300 to $800 \mathrm{mg} / \mathrm{kg}$ in Pinot Noir, 700 to $900 \mathrm{mg} / \mathrm{kg}$ in Blaufränkish, 900 to $1100 \mathrm{mg} / \mathrm{kg}$ in Barbera and Syrah and 1100 to $1300 \mathrm{mg} / \mathrm{kg}$ in Merlot, Refosk and Cabernet Sauvignon (Vrhovsek et al., 2002), whereas in 14 Sardinian red grape varieties the total extractable anthocyanin content ranged from 800 to $2000 \mathrm{mg} / \mathrm{kg}$ (Vacca et al., 2009). In this study, Vranac and Cabernet Sauvignon grapes proved to be highest in anthocyanins compared to Kratosija. In Vitis vinifera grape varieties, anthocyanins are located only in the skin of the grape berries, and their content in grapes and wines is influenced by the size of the berry (RomeroCascales et al., 2005). Vranac and Kratosija grapes are almost twice the size of Cabernet Sauvignon grapes. The highest content of anthocyanins (Fig. 2) in terms of $\mathrm{mg} / \mathrm{kg}$ skin FM was found in Vranac grapes (8 759 and $6929 \mathrm{mg} / \mathrm{kg}$ skin FM in 2011 and 2012 respectively), followed by Cabernet Sauvignon (5 985 and $4621 \mathrm{mg} / \mathrm{kg}$ skin FM) and Kratosija (3428 and $3479 \mathrm{mg} / \mathrm{kg}$ skin FM) (Fig. 2). Such a result is a further confirmation that Vranac is a variety synthesising very high levels of anthocyanins.

The average extractable LMP content was the highest in Cabernet Sauvignon grapes (2 006 and $1690 \mathrm{mg} / \mathrm{kg}$ in 2011 and 2012, respectively). Statistically lower contents of LMP were found in Vranac grapes (1 103 and $846 \mathrm{mg} / \mathrm{kg}$ in 2011 and 2012 respectively) and in the Kratosija grapes from 2012 (976 mg/kg). The LMP content in Kratosija grapes from 2011 (1 $413 \mathrm{mg} / \mathrm{kg}$ ) was not significantly different compared to the Cabernet Sauvignon grapes from 2011. Similarly, the average extractable HMP content was significantly higher in the Cabernet Sauvignon grapes (2 705 and $2805 \mathrm{mg} / \mathrm{kg}$ in 2011 and 2012 respectively) compared to Vranac and Kratosija. The average extractable HMP content did not 
TABLE 3

Content of extractable polyphenols (TP-total polyphenols, TA-total anthocyanins, LMP-low-molecular mass proanthocyanidins, HMP - high-molecular mass proanthocyanidins) in Vranac, Kratosija and Cabernet Sauvignon fresh grape berries.

\begin{tabular}{|c|c|c|c|c|c|c|c|c|}
\hline \multirow[b]{2}{*}{ Locality } & \multicolumn{4}{|c|}{2011} & \multicolumn{4}{|c|}{2012} \\
\hline & $\begin{array}{c}\mathrm{TP} \\
(\mathrm{mg} / \mathrm{kg}(+) \\
\text { catechin) }\end{array}$ & $\begin{array}{c}\text { TA } \\
(\mathrm{mg} / \mathrm{kg})\end{array}$ & $\begin{array}{c}\text { LMP } \\
(\mathrm{mg} / \mathrm{kg}(+) \\
\text { catechin) }\end{array}$ & $\begin{array}{c}\text { HMP } \\
\text { (mg/kg } \\
\text { cyanidin } \\
\text { chloride) }\end{array}$ & $\begin{array}{c}\mathrm{TP} \\
(\mathrm{mg} / \mathrm{kg}(+) \\
\text { catechin })\end{array}$ & $\begin{array}{c}\text { TA } \\
(\mathrm{mg} / \mathrm{kg})\end{array}$ & $\begin{array}{c}\text { LMP } \\
(\mathrm{mg} / \mathrm{kg}(+) \\
\text { catechin) }\end{array}$ & $\begin{array}{c}\text { HMP } \\
\text { (mg/kg } \\
\text { cyanidin } \\
\text { chloride) }\end{array}$ \\
\hline \multicolumn{9}{|c|}{ VRANAC } \\
\hline L1 & 1505 & 1149 & 774 & 785 & 1854 & 1075 & 946 & 1778 \\
\hline L2 & 2174 & 881 & 1392 & 1403 & 1550 & 1408 & 1096 & 1926 \\
\hline L3 & 2353 & 1136 & 1785 & 1716 & 1843 & 1166 & 874 & 1791 \\
\hline L4 & 1741 & 721 & 874 & 995 & 1325 & 935 & 689 & 1442 \\
\hline L5 & 2139 & 999 & 1067 & 1564 & 1480 & 1177 & 642 & 1395 \\
\hline L7 & 1534 & 873 & 727 & 1199 & 1534 & 917 & 830 & 1527 \\
\hline Mean & $1908 \mathrm{ab}$ & 960 a & $1103 \mathrm{~b}$ & $1277 \mathrm{~b}$ & $1598 \mathrm{ab}$ & $1113 a$ & $846 \mathrm{~b}$ & $1643 \mathrm{~b}$ \\
\hline \multicolumn{9}{|c|}{ KRATOSIJA } \\
\hline L1 & 1988 & 450 & 1726 & 2072 & 852 & 417 & 901 & 1197 \\
\hline L2 & 1983 & 497 & 1653 & 2069 & 1065 & 568 & 961 & 1532 \\
\hline L3 & 2038 & 505 & 1862 & 1368 & 1049 & 565 & 878 & 1469 \\
\hline L6 & 1356 & 436 & 936 & 1091 & 1675 & 529 & 1400 & 2426 \\
\hline L9 & 1128 & 394 & 888 & 2148 & 843 & 506 & 740 & 1114 \\
\hline Mean & $1699 \mathrm{~b}$ & $456 \mathrm{~b}$ & $1413 \mathrm{ab}$ & $1750 \mathrm{~b}$ & $1097 \mathrm{~b}$ & $517 \mathrm{c}$ & $976 \mathrm{~b}$ & 1548 b \\
\hline \multicolumn{9}{|c|}{ CABERNET SAUVIGNON } \\
\hline L1 & 2991 & 1064 & 2177 & 2112 & 2380 & 995 & 1932 & 3402 \\
\hline L2 & 2241 & 852 & 1611 & 2585 & 1875 & 981 & 1860 & 3356 \\
\hline L5 & 3861 & 1078 & 3449 & 3501 & 1845 & 710 & 1430 & 2646 \\
\hline L6 & 3241 & 1411 & 1972 & 3562 & 1841 & 825 & 2000 & 3550 \\
\hline L8 & 2076 & 808 & 1581 & 2323 & 2614 & 816 & 1389 & 2143 \\
\hline L10 & 1819 & 994 & 1244 & 2146 & 1544 & 836 & 1528 & 1734 \\
\hline Mean & 2705 a & 1035 a & 2006 a & 2705 a & 2017 a & 861 b & $1690 \mathrm{a}$ & 2805 a \\
\hline sign. F & $*$ & $* * *$ & $*$ & $* * *$ & $* *$ & $* * *$ & $* * *$ & $* *$ \\
\hline
\end{tabular}

ANOVA was used to compare data (n.s. not significant, $* p \leq 0.05, * * p \leq 0.01, * * * p \leq 0.001$ ). Different lower-case letters indicate significant differences of means between varieties using Tukey's HSD test $(p \leq 0.05)$.

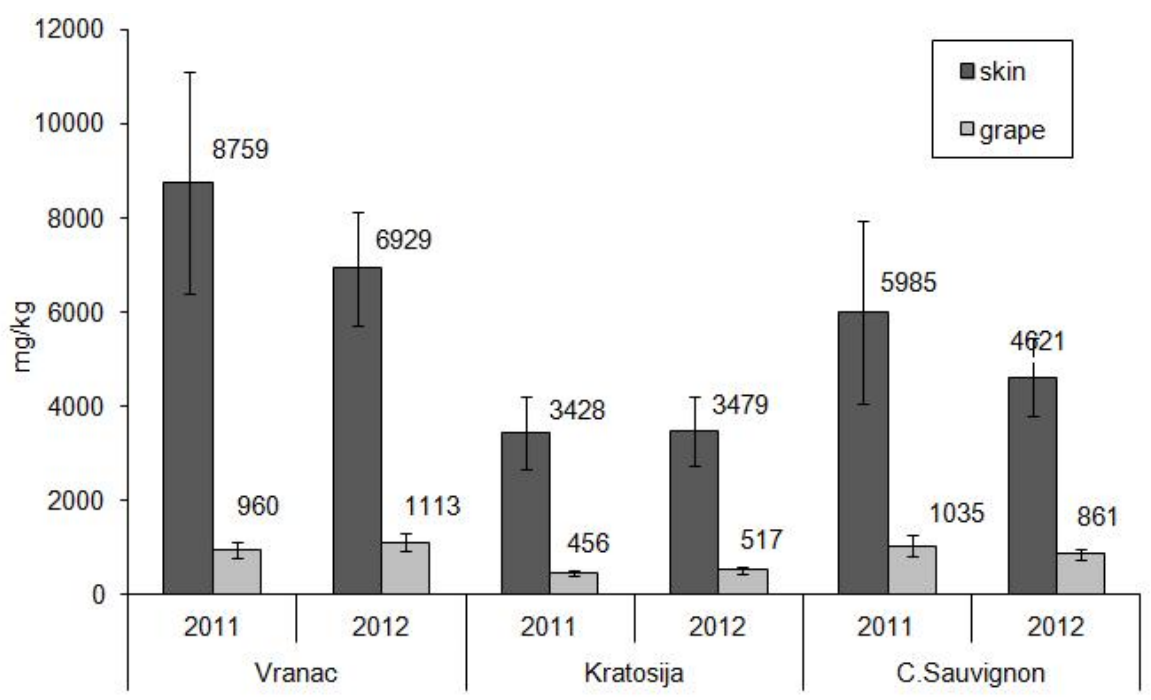

FIGURE 2

Content of extractable anthocyanins in the skin of grape berries ( $\mathrm{mg} / \mathrm{kg}$ skin fresh mass) and in the grape berries (mg/kg grape fresh mass) of the different varieties: Vranac $(n=6)$, Kratosija $(n=5)$ and Cabernet Sauvignon $(n=6)$. The error bars represent the standard deviation of the content from different locations. 
differ significantly between the Vranac grapes (1 $277 \mathrm{mg} / \mathrm{kg}$ and $1643 \mathrm{mg} / \mathrm{kg}$ in 2011 and 2012 respectively) and the Kratosija grapes (1 $750 \mathrm{mg} / \mathrm{kg}$ and $1548 \mathrm{mg} / \mathrm{kg}$ in 2011 and 2012 respectively). Extractable HMP contents in Cabernet Sauvignon grapes were in agreement with results obtained by Mattivi et al. (2002a) and Vrhovsek et al. (2002), who reported contents of HMP ranging between 2500 and 2800 $\mathrm{mg} / \mathrm{kg}$ and 2300 to $2700 \mathrm{mg} / \mathrm{kg}$ of grape FM, respectively.

\section{The impact of the vineyard location on the polyphenol} content in grapes

Differences in grape composition regarding extractable total polyphenols, anthocyanins, LMP and HMP contents were also found among vineyard locations in the Podgorica winegrowing area (Table 3), and similar outcomes were observed for the microvinified wines (Table 4). In the Podgorica winegrowing area, vineyards at locations L1 to L8 lie between 25 and $50 \mathrm{~m}$ above sea level (m.a.s.1.), whereas vineyards L9 (Kratosija) and L10 (Cabernet Sauvignon) lie between 250 and 400 m.a.s.l. (Fig. 1B). The altitude of vineyards was found to have an impact on the levels of anthocyanins in the grapes, i.e. higher vineyard sites were reported to be advantageous to the biosynthesis of anthocyanins (Mateus et al., 2002). Catechin monomers, procyanidin dimers, trimer $\mathrm{C} 1$ and total extractable proanthocyanidins proved to be higher in both the skins and seeds of grapes growing at lower altitudes (Mateus et al., 2001). It was indeed found in both years that total polyphenols and LMP and HMP contents in Kratosija and Cabernet Sauvignon grapes from L9 and L10 respectively were the lowest among all investigated locations (except the LMP content in Kratosija in 2011), and similar outcomes were obtained in microvinified wines of Kratosija (Table 4). Vranac grapes originating from L2 and L3 proved to be high in the sum of extractable LMP and HMP contents for both 2011 and 2012 (Table 3). The extractable LMP and HMP contents in Kratosija grapes varied between the two years, i.e. from the highest content in L1 and the lowest content in L6 in 2011 to the lowest content in L1 and the highest content in L6 in 2012. The sum of extractable LMP and HMP

TABLE 4

Content of polyphenols (TP - Total polyphenols, TA - Total anthocyanins, LMP - low-molecular mass proanthocyanidins, HMP - high-molecular mass proanthocyanidins) in four-month-old wines from Vranac, Kratosija and Cabernet Sauvignon from the 2011 and 2012 vintages.

\begin{tabular}{|c|c|c|c|c|c|c|c|c|}
\hline \multirow[b]{2}{*}{ Locality } & \multicolumn{4}{|c|}{2011} & \multicolumn{4}{|c|}{2012} \\
\hline & $\begin{array}{l}\text { TP } \\
(\mathrm{mg} / \mathrm{L}(+) \\
\text { catechin) }\end{array}$ & $\begin{array}{l}\text { TA } \\
(\mathrm{mg} / \mathrm{L})\end{array}$ & $\begin{array}{l}\text { LMP } \\
(\mathrm{mg} / \mathrm{L}(+) \\
\text { catechin) }\end{array}$ & $\begin{array}{l}\text { HMP } \\
\text { (mg/L } \\
\text { cyanidin } \\
\text { chloride) }\end{array}$ & $\begin{array}{l}\mathrm{TP} \\
(\mathrm{mg} / \mathrm{L}(+) \\
\text { catechin) }\end{array}$ & $\begin{array}{l}\text { TA } \\
(\mathrm{mg} / \mathrm{L})\end{array}$ & $\begin{array}{l}\text { LMP } \\
\text { (mg/L (+) } \\
\text { catechin) }\end{array}$ & $\begin{array}{l}\text { HMP } \\
\text { (mg/L } \\
\text { cyanidin } \\
\text { chloride) }\end{array}$ \\
\hline
\end{tabular}

\begin{tabular}{|c|c|c|c|c|c|c|c|c|}
\hline \multicolumn{9}{|c|}{ VRANAC } \\
\hline L1 & 1107 & 641 & 176 & 703 & 1515 & 945 & 657 & 1802 \\
\hline $\mathrm{L} 2$ & 1000 & 474 & 173 & 1405 & 1650 & 1107 & 581 & 2093 \\
\hline L3 & 1485 & 720 & 322 & 1717 & 1727 & 900 & 868 & 2090 \\
\hline L4 & 1146 & 734 & 281 & 995 & 885 & 617 & 350 & 913 \\
\hline L5 & 1602 & 813 & 400 & 1565 & 1101 & 758 & 290 & 913 \\
\hline L7 & 891 & 559 & 246 & 896 & 859 & 664 & 363 & 921 \\
\hline Mean & 1205 & $657 \mathrm{~b}$ & 266 & 1214 & 1290 & 832 a & 518 & 1455 \\
\hline \multicolumn{9}{|c|}{$\overline{\text { KRATOSIJA }}$} \\
\hline L1 & 877 & 241 & 251 & 988 & 944 & 500 & 551 & 1049 \\
\hline $\mathrm{L} 2$ & 937 & 268 & 292 & 860 & 1015 & 458 & 579 & 994 \\
\hline L3 & 1515 & 366 & 622 & 1360 & 1147 & 370 & 681 & 654 \\
\hline L9 & 837 & 394 & 272 & 889 & 736 & 387 & 414 & 686 \\
\hline Mean & 1042 & $317 \mathrm{c}$ & 359 & 1024 & 961 & $429 \mathrm{~b}$ & 556 & 846 \\
\hline \multicolumn{9}{|c|}{ CABERNET SAUVIGNON } \\
\hline L1 & 1085 & 964 & 350 & 1020 & 1461 & 514 & 963 & 1924 \\
\hline L2 & 1109 & 570 & 297 & 703 & 1679 & 572 & 1059 & 2587 \\
\hline L5 & 1387 & 1018 & 349 & 1302 & 1367 & 484 & 516 & 788 \\
\hline L6 & 1538 & 1111 & 747 & 1889 & 1393 & 521 & 790 & 1607 \\
\hline L8 & 1388 & 1063 & 670 & 1471 & 1065 & 512 & 607 & 916 \\
\hline Mean & 1301 & 945 a & 483 & 1277 & 1393 & $521 \mathrm{~b}$ & 787 & 1564 \\
\hline sign. $\mathrm{F}$ & n.s. & $* * *$ & n.s. & n.s. & n.s. & $* * *$ & n.s. & n.s. \\
\hline
\end{tabular}

ANOVA was used to compare data (n.s. not significant, $* p \leq 0.05, * * p \leq 0.01$, $* * * p \leq 0.001$ ). Different lower-case letters indicate significant differences of means between varieties using Tukey's HSD test $(p \leq 0.05)$. 
contents in Cabernet Sauvignon grapes was higher in L1, L2, L5 and L6 compared to L8 and L10 in both investigated years (Table 3). Grapes obtained from locations with high tannin levels can be used for a desired wine style, taking into consideration the winemaking protocol. However, at this stage it is too early to characterise vineyard locations based on polyphenol potential. Instead, a multiyear monitoring approach is needed for statistically relevant vineyard mapping.

The impact of seasonal variation (2011 and 2012) on the extractable polyphenols in grapes at different vineyard locations is evident. Climatic conditions play an important role in polyphenol biosynthesis in grapes, resulting in markedly higher levels of polyphenol contents in grapes grown in locations or areas with higher average daytime temperatures and decreased precipitation (Lee et al., 2009). The total polyphenol content in grapes proved to be higher in 2011, which was characterised by high vegetation temperatures and lower precipitation compared to 2012 for all three investigated varieties.

\section{Distribution of low- and high-molecular mass proanthocyanidins between the skin and seeds of the grape berries}

The distribution of proanthocyanidins between the seeds and skins of grape berries is known to be affected by grape variety (Mattivi et al., 2002b, 2009), although the genetic control of the qualitative and quantitative proanthocyanidin composition between berry skin and seeds is complex and still poorly understood (Huang et al., 2012). Fig. 3 represents the two-year average distribution of extractable LMP and HMP between grape berry skins and seeds for the varieties Vranac, Kratosija and Cabernet Sauvignon. The two-year average distribution of LMP between skins and seeds was 34:66, 39:61 and 49:51, whereas the distribution of HMP between skins and seeds was 67:33, 62:38 and 64:36 for Vranac, Kratosija and Cabernet Sauvignon respectively
(Fig. 3). Vrhovsek et al. (2002), Mattivi et al. (2002a) and Vacca et al. (2009) reported similar results regarding extractable proanthocyanidin distribution in different red Vitis vinifera grapes, with increased levels of LMP in the seeds and increased levels of HMP in the skins of the grape berries.

\section{Contents of total polyphenols, low- and high-molecular mass proanthocyanidins and total anthocyanins in Vranac, Kratosija and Cabernet Sauvignon wines}

Contents of total polyphenols, low- and high-molecular mass proanthocyanidins and total anthocyanins in four-monthsold Vranac, Kratosija and Cabernet Sauvignon wines from different vineyard locations in Podgorica district in 2011 and 2012 are shown in Table 4.

On average, the Cabernet Sauvignon wines had a higher content of total polyphenols in both years investigated (1 301 and $1393 \mathrm{mg} / \mathrm{L}$ in 2011 and 2012, respectively) compared to the Vranac wines (1 205 and $1290 \mathrm{mg} / \mathrm{L}$ ) and Kratosija wines (1 042 and $961 \mathrm{mg} / \mathrm{L}$ ), although the differences were not statistically significant. The anthocyanin content was significantly higher in the Cabernet Sauvignon wines from 2011 (945 mg/L) compared to the Vranac $(657 \mathrm{mg} / \mathrm{L})$ and Kratosija wines (317 mg/L). Vranac wines made during 2012 proved to be significantly higher in anthocyanin content (832 mg/L) compared to the Cabernet Sauvignon $(521 \mathrm{mg} / \mathrm{L})$ and Kratosija wines (429 mg/L). Kratosija wines showed the lowest anthocyanin content in both 2011 and 2012. The mean LMP content was also the highest for the Cabernet Sauvignon wines (483 and $787 \mathrm{mg} / \mathrm{L}$ in 2011 and 2012, respectively). Lower contents, although not statistically significant, were found in Kratosija wines (359 and $556 \mathrm{mg} / \mathrm{L}$ in 2011 and 2012, respectively) and in Vranac wines (266 and $518 \mathrm{mg} / \mathrm{L}$ in 2011 and 2012 respectively). The average HMP content was the highest in Cabernet Sauvignon wines (1 277 and $1564 \mathrm{mg} / \mathrm{L}$ in 2011 and 2012 respectively), followed by Vranac wines (1 $214 \mathrm{mg} / \mathrm{L}$ and $1455 \mathrm{mg} / \mathrm{L}$ in 2011 and 2012,

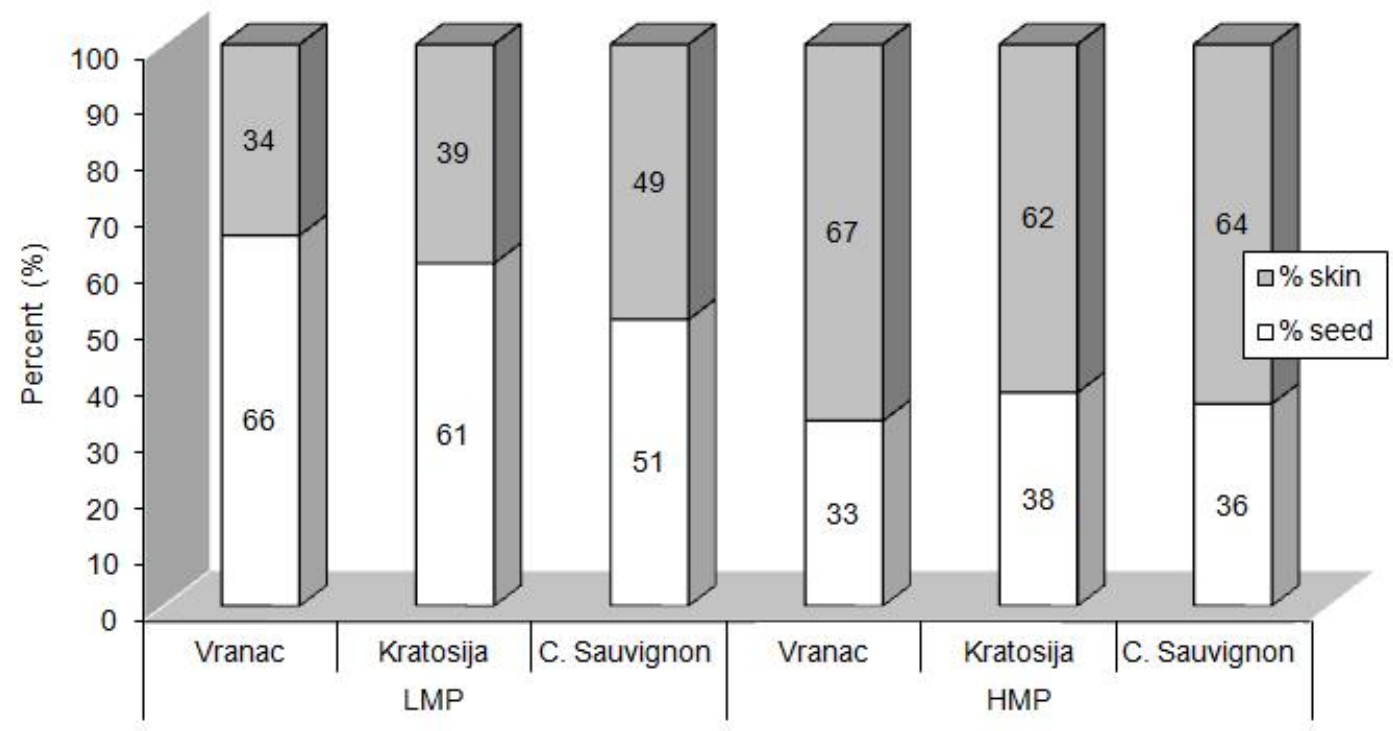

FIGURE 3

Distribution of extractable low-molecular mass (LMP) and high-molecular mass (HMP) proanthocyanidins between skins and seeds of Vranac, Kratosija and Cabernet Sauvignon grapes. 
respectively) and Kratosija wines (1 024 and $846 \mathrm{mg} / \mathrm{L}$ in 2011 and 2012, respectively). In both years, the trend in the polyphenol contents determined in wines was correlated well with the contents found in the grapes (Table 3 ). However, lower contents of LMP were found in wines than in grape extracts, thus concluding that the extraction of LMP was less efficient in microvinification than in the grape extraction process. The reason for this could be that the yeasts used were not standardised, the press fraction was missing or the maceration time was too short to allow for a proper extraction of polyphenols from the grape seeds.

\section{CONCLUSIONS}

Polyphenol compounds in red wine are directly linked to eventual wine flavour, colour and ageing characteristics. The evaluation of polyphenol compounds in grapes and wines of Montenegrin red grape varieties provided a technological characterisation that can be used by both winegrowers and winemakers to develop proper programmes for phenolic management. Cabernet Sauvignon grapes proved to be highest in extractable total polyphenols, anthocyanins (Vranac grapes showed increased levels), and low- and highmolecular mass proanthocyanidins during 2011 and 2012. The same trend was also found in the microvinified wines. Vranac grapes showed lower polyphenol potential in comparison to Cabernet Sauvignon, but a high anthocyanin content that gave the wines an intense red colour. The grapes of Vranac showed the highest anthocyanin content in the grape skins in comparison to Cabernet Sauvignon and Kratosija. However, the larger berry size (almost twice) of Vranac and Kratosija in comparison to Cabernet Sauvignon dilutes the content of polyphenols in the grapes. Vranac could be considered as a variety with medium to long ageing potential, although the optimal ripeness of the grapes and suitable winemaking procedures have to be considered. Kratosija grapes had the highest TSS content at the time of sampling and a similar content of extractable total polyphenols, LMP and HMP as for Vranac. The main difference between Vranac and Kratosija was the lower content of anthocyanins in both the grapes and wines of Kratosija compared to Vranac. Kratosija can be considered a variety with lower polyphenol potential compared to Vranac and Cabernet Sauvignon.

As regards Vranac and Kratosija grapes, a strange relationship was found between sugar and polyphenol accumulation. Further studies (cluster thinning, canopy to crop rate) therefore are needed in order to better understand the best equilibrium for these varieties. As regards Cabernet Sauvignon grapes, it would be good to perform cluster thinning in colder seasons in order to obtain better maturation. It would also be profitable to take care of water stress in hot seasons to get better maturation.

Considering the vineyard locations, it could be postulated that increased levels of polyphenols were present in grapes originating from locations between $25 \mathrm{~m}$ and $50 \mathrm{~m}$. a. s. 1 . compared to those at $250 \mathrm{~m}$ and $400 \mathrm{~m}$. a. s. 1 .. However, only two locations out of the nine lie at higher altitudes. Furthermore, it was found that climatic conditions during 2011 and 2012 had an impact on polyphenol biosynthesis in grapes from different vineyard locations. Two-year monitoring of total extractable tannins in grapes from different locations led to the identification of locations with improved grape tannin potential: L2 and L3 for Vranac and L5 and L6 for Cabernet Sauvignon. No conclusion can be drawn regarding the grape polyphenol potential of the locations for the Kratosija variety. A multiyear study therefore will be carried out in the future to evaluate the polyphenol potential of grapes from different vineyard locations.

\section{LITERATURE CITED}

Avramov, L., 1991. Vinogradarstvo. Nolit, Beograd.

Bozinovic, Z., 2005. Ampelografija. Akademik. Skopje.

Broadhurst, R.B. \& Jones, W.T., 1978. Analysis of condensed tannins using acidified vanillin. J. Sci. Food Agric. 29, 788-794.

Brossaud, F., Cheynier, V. \& Noble, A.C., 2001. Bitterness and astringency of grape and wine polyphenols. Aus. J. Grape Wine Res. 7, 33-39.

Chira, K., Schmauch, G., Saucier, C., Fabre, S. \& Teissedre, P.L., 2009. Grape variety effect on proanthocyanidin composition and sensory perception of skin and seed tannin extracts from Bordeaux wine grapes (Cabernet Sauvignon and Merlot) for two consecutive vintages (2006 and 2007). J. Agric. Food Chem. 57 (2), 545-553.

Di Stefano, R. \& Guidoni, S., 1989. The analysis of total polyphenols in musts and wines. Vignevini 1/2, 47-52.

Di Stefano, R., Cravero, M.C. \& Gentilini, N., 1989. Methods for the study of wine polyphenols. L'Enotecnico 5, 83-89.

Gambuti, A., Capuano, R., Lecce, L., Fragasso, M.G. \& Moio, L., 2009. Extraction of phenolic compounds from 'Aglianico' And 'Uva di Troia' grape skin and seeds in model solutions: Influence of ethanol and maceration time. Vitis 48, (4), 193-200.

Huang, Y.-F., Doligez, A., Fournier-Level, A., Le Cunff, L., Bertrand, Y., Canaguier, A., Morel, C., Miralles, V., Veran, F., Souquet, J.-M., Cheynier, V., Terrier, N. \& This, P., 2012. Dissecting genetic architecture of grape proanthocyanidin composition through quantitative trait locus mapping. BMC Plant Biology 12, 30 .

Ivanova, V., Stefova, M. \& Chinnici, F., 2010. Determination of the polyphenol contents in Macedonian grapes and wines by standardized spectrophotometric methods. J. Serb. Chem. Soc. 75, 45-59.

Ivanova, V., Stefova, M., Vojnoski, B., Dörnyei, Á., Márk, L., Dimovska, V., Stafilov, T. \& Kilár, F., 2011. Identification of polyphenolic compounds in red and white grape varieties grown in R. Macedonia and changes of their content during ripening. Food Res. Int. 44, 2851-2860.

Lee, J.-E., Hwang, G.-S., Van den Berg, F., Lee, C.-H. \& Hong, Y.-S., 2009. Evidence of vintage effects on grape wines using $1 \mathrm{H}$ NMR-based metabolomic study. Anal. Chim. Acta. 648, 71-76.

Mateus, N., Machado, J.M. \& De Freitas, V., 2002. Development changes of anthocyanins in Vitis vinifera grapes grown in the Douro Valley and concentration in respective wines. J. Sci. Food Agric. 82, 1689-1695.

Mateus, N., Marques, S., Gonçalves, A.C., Machado, J.-M. \& De Freitas, V., 2001. Proanthocyanidin composition of red Vitis vinifera varieties from the Douro Valley during ripening: Influence of cultivation altitude. Am. J. Enol. Vitic. 52, 115-121.

Mattivi, F., Prast, A., Nicolini, G. \& Valenti, L., 2002b. Validazione di un nuovo metodo per la misura del potenziale polifenolico delle uve rosse e discussione del suo campo di applicazione in enologia. Riv. Vitic. Enol. 2/3, $55-74$.

Mattivi, F., Vrhovsek, U., Masuero, D. \& Trainotti, D., 2009. Differences in the amount and structure of extractable skin and seed tannins amongst red grape varieties. Aus. J. Grape Wine Res. 15, 27-35. 
Mattivi, F., Zulian, C., Nicolini, G. \& Valenti, L., 2002a. Wine, biodiversity, technology, and antioxidants. Ann. N.Y. Acad. Sci. 957, 37-56.

MONSTAT - Statistical Office of Montenegro, 2013. Statistical Yearbook. MONSTAT, Podgorica.

OIV (International Organisation of Vine and Wine), 2011. Compendium of international methods of wine and must analysis, vol 1. International Organisation of Vine and Wine, Paris.

Pajovic, R., Popovic, T., Boskov, K. \& Beleski, K., 2009. Technologica characteristics of introducing varieties Merlot and Cabernet Sauvignon in the Podgorica wine growing region (Montenegro) and Skopje wine growing region (Macedonia). Agroznanje 10(1), 89-96.

Pajovic, R., Popovic, T., Mijovic, S. \& Vukoslavljevic, V., 2011. Economic, technological and polyphenolic characteristics of Vranac, Kratosija and Merlot grapes varieties and wines in Montenegro and Macedonia. In: Blesic, M. (ed). Proc. 22 $2^{\text {nd }}$ International Scientific-Expert Conference on Agriculture and Food Industry, 2011, Neum, Bosnia and Herzegovina. pp. $341-345$

Pejovic, L., 1988. Ampelografska proučavanja varijeteta Kratosije. [Ampelographic investigations of Kratosija biotypes]. Jugoslovensko vinogradarstvo i vinarstvo, Beograd, 34, 21-23.

Peleg, H., Gacon, K., Schlich, P. \& Noble, A.C., 1999. Bitterness and astringency of flavan 3-ol monomers, dimers and trimers. J. Sci. Food Agric. 79, 1123-1128.

Peyrot des Gachons, C. \& Kennedy, J.A., 2003. Direct method for determining seed and skin proanthocyanidin extraction in red wine. J. Agric. Food Chem. 51, 5877-5881.

Preys, S., Mazerolles, G., Courcoux, P., Samson, A., Fischer, U., Hanafi, M., Bertrand, D. \& Cheynier, V., 2006. Relationship between polyphenolic composition and some sensory properties in red wine using multi way analyses. Anal. Chim. Acta 563, 126-136.
Ribéreau-Gayon, P., 1982. The anthocyanins of grapes and wine. In: Markakis P. (ed). Anthocyanins as food colors. Academic Press, New York. pp. $112-118$

Rigo, A., Vianello, F., Clementi, G., Rossetto, M., Scarpa, M., Vrhovšek, U. \& Mattivi, F., 2000. Contribution of proanthocyanidins to the peroxy radical scavenging capacity of some Italian red wines. J. Agric. Food Chem. 48, 1996-2002.

Robichaud, J.L. \& Noble, A.C., 1990. Astringency and bitterness of the selected phenolics in wine. J. Sci. Food Agric. 53, 343-353.

Rodrigo, R., Miranda, A. \& Vergara, L., 2011. Modulation of endogenous antioxidant system by wine polyphenols in human disease. Clin. Chim. Acta $412,410-424$.

Romero-Cascales, I., Ortega-Regules, A., López-Roca, J., FernándezFernández, J. \& Gómez-Plaza, E., 2005. Differences in anthocyanin extractability from grapes to wines according to variety. Am. J. Enol. Vitic. $56,212-219$

Somers, T.C., 1971. The polymeric nature of wine pigments. Phytochemistry $10,2175-2186$.

Ulicevic, M., 1966. Prilog proucavanju osobina najvažnijih sorata vinove loze gajenih u SR Crnoj Gori. [Contribution to characterization of the most important grapevine varieties grown in Republic of Montenegro]. Arhiv za poljoprivredne nauke $23,1-100$.

Vacca, V., Del Caro, A., Millela, G.G. \& Nieddu, G., 2009. Preliminary characterisation of Sardinian red grape cultivars (Vitis vinifera L.) according to their phenolic potential. S. Afr. J. Enol. Vitic. 30, (2), 93-100.

Vrhovsek, U., Mattivi, F. \& Waterhouse, A.L., 2001. Analysis of red wine phenolics: comparison of HPLC and spectrophotometric methods. Vitis 40(2), 87-91.

Vrhovsek, U., Vanzo, A., Koruza, B. \& Korosec-Koruza, Z., 2002. Polifenolni potencial slovenskega rdecega grozdja. [Polyphenol potential of Slovenian red grapes]. In: Puconja, M. (ed). Vinogradi in vina za tretje tisocletje. Otocec, Slovenia. pp. 359 - 367. 